\title{
UPAYA MENINGKATKAN KEAKTIFAN DAN HASIL BELAJAR ILMU BAHAN BANGUNAN MELALUI PENERAPAN MODEL PEMBELAJARAN TIME TOKEN PADA SISWA KELAS X PROGRAM KEAHLIAN TEKNIK BANGUNAN DI SMK NEGERI 2 MEDAN
}

\author{
Togi Supriadi Napitupulu1, Sempurna Perangin-Angin ${ }^{2}$ \\ ${ }^{1}$ Alumni Program Studi Pendidikan Teknik Bangunan, Fakultas Teknik UNIMED \\ 2Dosen Pengajar Jurusan Pendidikan Teknik Bangunan, Fakultas Teknik UNIMED \\ (sempurnaperangin@gmail.com)
}

\begin{abstract}
ABSTRAK
Penelitian ini bertujuan untuk meningkatkan keaktifan dan hasil belajar ilmu bahan bangunan siswa melalui penerapan model pembelajaran Time Token pada siswa kelas X SMK Negeri 2 Medan semester ganjil Tahun Ajaran 2014/2015 yang berjumlah 30 orang. Jenis penelitian ini adalah Penelitian Tindakan Kelas (PTK). Hasil ujicoba instrumen yang dilakukan pada siklus pertama diperoleh 25 soal yang valid dan uji reabilitas diperoleh 0,9169 . Siklus kedua diperoleh 25 soal valid dan uji reabilitas diperoleh 0.9181. Penelitian ini dikatakan berhasil diukur berdasarkan indikator rata-rata kumulatif aktivitas dan hasil belajar siswa mendapat nilai 80 sekurang-kurangnya $80 \%$ di dalam kelas dengan baik dalam pembelajaran Memahami Ilmu Bahan Bangunan.Hasil penelitian hasil belajar menunjukkan bahwa pada siklus I nilai hasil belajar yang diperoleh $75 \%$ sedangkan siklus ke II nilai hasil belajar yang diperoleh meningkat menjadi $83 \%$. Aktivitas siswa menunjukkan bahwa pada siklus I diperoleh nilai $75 \%$ sedangkan siklus ke II nilai aktivitas siswa meningkat menjadi 85\%. Dapat disimpulkan bahwa penerapan model pembelajaran Time Token untuk meningkatkan Aktivitas dan Hasil Belajar Ilmu Bangunan Pada Siswa Kelas X SMK Negeri 2 Medan Program Keahlian Teknik Gambar Bangunan Tahun Ajaran 2014/2015 membuktikan peningkatan hasil belajar dan aktivitas belajar siswa.
\end{abstract}

Kata kunci: PembelajaranTime Token, Keaktifan, Hasil Belajar

\begin{abstract}
This study aims to improve the activity and the learning outcomes of students knowledge of building materials through the application of learning models Time Token in class X SMK Negeri 2 Medan Academic Year 2014/2015 totaling 30 people. This research is a Classroom Action Research (ACR). The results of tests performed on the instrument first cycle obtained 25 valid questions and test reliability obtained 0.9169 . The second cycle was obtained 25 valid questions and test reliability obtained by 0.9181 . This study was successful is measured by indicators of the average cumulative activity and learning outcomes of students scored 80 of at least $80 \%$ in class well in understanding knowledge of building materials instructional. Research study results showed that in the first cycle of learning outcomes obtained value $75 \%$ whereas the second cycle to the value of learning outcomes obtained increased to $83 \%$. Student activity shows that in the first cycle of $75 \%$ while the value obtained to the second cycle of student activity value increased to $85 \%$. It can be concluded that the application of learning models Time Token to improve the activity and Learning Outcomes Sciences Building In Class X SMK Negeri 2 Medan Skills Program Architecture Engineering Academic Year 2014/2015 proven to increase learning outcomes and student learning activities.
\end{abstract}

Keywords: Time Token Learning, Activity, Learning Outcomes, 


\section{Pendahuluan}

SMK Negeri 2 Medan merupakan salah satu SMK yang memiliki Program Keahlian Teknik Gambar Bangunan dan TeknikKonstruksi Bangunan, yang melaksanakan serangkaian kegiatan belajar yang meliputi berbagai mata pelajaran keteknikan. Salah satu mata pelajaran Ilmu Bahan Bangunan (IBB).

Berdasarkan hasil observasi yang dilakukan di SMK Negeri 2 Medan pada bulan juni 2014 hasil belajar Ilmu Bahan Bangunan khususnya pada siswa kelas X Program Keahlian Teknik Gambar Bangunan di SMK Negeri 2 Medan Tahun Pelajaran 2013/2014, nilai rata-rata mata pelajaranilmu bahan bangunan siswa adalah 75 . Artinya nilai yang dicapai siswa baru mencapai Kriteria Ketuntasan Minimal (KKM) yaitu $\geq 75$. Untuk lebih jelasnya dapat dilihat pada tabel dibawah ini:

Tabel 1. Nilai Rata-rata hasil belajar Ilmu Bahan Bangunan Kelas X SMK Negeri 2 Medan.

\begin{tabular}{|c|l|c|c|c|}
\hline T.A & Nilai & $\begin{array}{l}\text { Jumlah } \\
\text { Siswa } \\
\text { (Orang) }\end{array}$ & Persentase & Keterangan \\
\hline \multirow{5}{*}{$2012 /$} & $\leq 69$ & 6 & $13.88 \%$ & $\begin{array}{c}\text { Tidak } \\
\text { Kompeten }\end{array}$ \\
\cline { 2 - 5 } 2013 & $\begin{array}{l}7.00- \\
7.90\end{array}$ & 12 & $65.63 \%$ & $\begin{array}{c}\text { Cukup } \\
\text { Kompeten }\end{array}$ \\
\cline { 2 - 5 } & $\begin{array}{l}8.00- \\
8.90\end{array}$ & 7 & $10.49 \%$ & Kompeten \\
\cline { 2 - 5 } & $\begin{array}{l}9.00- \\
100\end{array}$ & - & & \\
\hline \multirow{5}{*}{$2013 /$} & $\leq 69$ & 3 & $21.50 \%$ & $\begin{array}{c}\text { Tidak } \\
\text { Kompeten }\end{array}$ \\
\cline { 2 - 5 } 2014 & $\begin{array}{l}7.00- \\
7.90\end{array}$ & 15 & $60.70 \%$ & $\begin{array}{c}\text { Cukup } \\
\text { Kompeten }\end{array}$ \\
\cline { 2 - 5 } & $\begin{array}{l}8.00- \\
8.90\end{array}$ & 4 & $7.80 \%$ & Kompeten \\
\cline { 2 - 5 } & $\begin{array}{l}9.00- \\
100\end{array}$ & - & & \\
\hline
\end{tabular}

Penelitian yang dilakukan ini adalah penelitian tindakan kelas (classroomaction research). Penelitian tindakan kelas digunakan dalam rangka pengumpulan data untuk perbaikan dan pengetahuan mengenai aktivitas pembelajaran Ilmu Bahan Bangunan. Setiap guru dalam penelitian tindakan kelas ini adalah sebagai pengamat atau sekaligus sebagai pelaksana tindakan. Dalam penelitian tindakan kelas ini dilaksanakan untuk melihat dan mengetahui apakah terjadi peningkatan hasil belajar pada siswa pada saat dilakukan evaluasi hasil belajar.

Berdasarkan latar belakang di atas, penulis tertarik untuk melakukan penelitian ini. Penelitian ini juga relevan (berguna secara langsung), signifikan (penting) dan data-datanya dapat diperoleh. Hasil penelitian ini penting untuk diketahui, oleh karena itu penulis melakukan penelitian dengan judul "Upaya Meningkatkan Keaktifan Dan Hasil Belajar Ilmu Bahan Bangunan Melalui Penerapan Model Pembelajaran Time Token Pada Siswa Kelas X Program Keahlian Teknik Bangunan di SMK Negeri 2 Medan Tahun".

\section{Kajian Teoritis}

\subsection{Hakikat Aktivitas Belajar Siswa}

Dalam hal kegiatan belajar, Rousseuau (dalam Sardiman 2004:96) memberikan penjelasan bahwa segala pengetahuan itu harus diperoleh dengan pengamatan sendiri, penyelidikan sendiri, dengan bekerja sendiri baik secara rohani maupun teknis. Tanpa ada aktivitas, proses belajar tidak mungkin terjadi. Lebih lanjut dikatakan, pada prinsipnya belajar adalah berbuat, tidak ada belajar jika tidak ada aktivitas. Itulah mengapa aktivitas merupakan prinsip yang sangat penting dalam interaksi belajar mengajar.

Paul B. Diedrich (dalam Sardiman 2009:101) membuat suatu daftar yang berisi 177 macam kegiatan siswa yang antara lain dapat digolongkan sebagai berikut :

a. Visual activities

b. Oral activities

c. Listening activities

d. Writing activities

e. Emotional activities

Dari pembahasan yang telah di jelaskan diatas, maka dapat disimpulkan bahwa aktivitas belajar siswa memiliki prinsip-prinsip dimana berpengaruh dalam aktivitas belajar siswa, diantaranya adalah melihat/memandang, mendengarkan, mencicipi/meraba, menulis atau mencatat, membaca, mengamati, mengingat, berpikir, serta latihan atau praktek. Karena dari semua prinsip-prinsip yang telah disebutkan diatas merupakan prinsip yang berkesinambungan dalam proses aktivitas belajar berlangsung. 


\section{UpayaMeningkatkan Keaktifan dan Hasil Belajar IImu Bahan Bangunan Melalui Penerapan Model Pembelajaran Time Token Pada Siswa Kelas X Program Keahlian Teknik Bangunan di SMK Negeri 2 Medan}

\subsection{Hakikat Hasil Belajar Ilmu Bahan Bangunan}

Pada hakikatnya belajar bukanlah sekedar mengumpulkan pengetahuan. Belajar adalah proses mental yang terjadi dalam diri seseorang, sehingga menyebabkan munculnya perubahan perilaku secara positif, dikatakan positif oleh karena perubahan perilaku itu bersifat lebih baik dari sebelumnya karena adanya penambahan dan cendrung tahan lama dan tidak mudah dilupakan dalam aspek pengetahuan, sikap, maupun psikomotorik. Dengan demikian seorang siswa dapat dikatakan belajar apabila sudah terjadi perubahan dalam dirinya.

Secara garis besar dapat dikemukakan bahwa materi pembelajaran adalah pengetahuan, keterampilan, dan sikap yang harus dikuasai peserta didik dalam rangka memenuhi standar kompetensi yang ditetapkan.Salah satu faktor penting yang sangat berpengaruh terhadap keberhasilan pembelajaran secara keseluruhan adalah kemampuan dan keberhasilan guru merancang materi pembelajaran. Artinya, materi yang ditentukan untuk kegiatan pembelajaran hendaknya materi yang benar-benar menunjang tercapainya Standar Kompetensi dan Kompetensi Dasar serta tercapainya Indikator.

Cara menilai hasil belajar yang dilaksanakan pada sekolah SMK Negeri 2 Medan ialah tes objektif atau bentuk pilihan berganda. Dimana tes objektif ini memiliki soal sebanyak 30 butir pada siklus pertama dan 30 butir juga pada Siklus kedua. Tes objektif ini memiliki empat pilihan jawaban, dimana tiga jawaban yang tidak tepat atau menjebak dan satu jawaban yang tepat dan benar.

\subsection{Hakikat Model Pembelajaran Time Token}

Menurut (Idris 2011:12) model pembelajaran time token adalah strategi pembelajaran yang digunakan untuk menghindari sikap siswa yang mendominasi pembicaraan dan sikap diam sama sekali.Jadi model pembelajaran time token adalah model pembelajaran yang lebih mengarah pada semua siswa untuk aktif baik dalam bertanya maupun mengemukakan pendapat masingmasing siswa.

Dalam memberikan tugas yang baik, guru hendaklah memperhatikan dan menempuh langkah-langkah berikut ini:

a. Guru menjelaskan tujuan pembelajaran atau kompetensi dasar. b. Guru mendiskusikan kelas untuk melaksanakan diskusi.

c. Guru memberi tugas kepada siswa.

d. Guru memberikan setiap kupon berbicara dengan waktu \pm 30 detik, dan setiap siswa diberi sejumlah nilai sesuai waktu keadaan.

e. Bila selesai bicara kartu bicara yang dipegang siswa diserahkan pada guru.

f. Sehingga semua siswa memiliki hak bicara yang sama, dan sampai semua siswa berbicara dan berpendapat.

g. Guru dan siswa membuat kesimpulan bersama dari hasil diskusi.

h. Guru menutup pelajaran.

Hipotesis yang diajukan dalam penelitian ini adalah :

a. Dengan menggunakan model pembelajaran Time Token dapat meningkatkan keaktivan siswa dalam pembelajaran Ilmu Bangunan pada siswa kelas $X$ program keahlian Teknik Gambar Bangunan SMK Negeri 2 Medan Tahun Pelajaran 2013/2014.

b. Dengan menerapkanmodel pembelajaranTime Token dapat meningkatkan hasil belajar siswa kelas X program keahlian Teknik Gambar Bangunan SMK Negeri 2 Medan Tahun Pelajaran 2013/2014.

\section{Metodologi Penelitian}

\subsection{Tempat dan Waktu Penelitian}

Penelitian tindakan kelas ini dilaksanakan di SMK Negeri 2 Medan, Program Keahlian Teknik Bangunan Pada Mata Pelajaran Ilmu Bahan Bangunan. Penelitian ini dilaksanakan pada kelas X semester genap Tahun Ajaran 2014/2015.

\subsection{Subjek Penelitian}

Subjek penelitian di dalam pelaksanaan penelitian ini yaitu siswa kelas XProgram Keahlian Teknik Bangunan di SMK Negeri 2 Medan Tahun Pelajaran 2014/2015 dengan jumlah siswa sebanyak 30 orang.

\subsection{Objek Penelitian}

Objek penelitian ini adalah penerapan model pembelajaran time token untuk meningkatkan aktivitas dan hasil belajar Menerapkan Ilmu Bahan Bangunan pada siswa kelas X SMK Negeri 2 Medan.

\subsection{Definisi Operasional}




\section{Togi Supriadi Napitupulu - Sempurna Perangi-Angin}

Definisi Operasional dalam penelitian ini adalah sebagai berikut:
a. Aktivitas belajar siswa
b. Belajar Ilmu Bahan Bangunan
c. Model pembelajaran Time Token.

\subsection{Prosedur Penelitian}

Penelitian yang dilakukan ini adalah penelitian tindakan kelas (classroomaction research). Setiap guru dalam penelitian tindakan kelas ini adalah sebagai pengamat atau sekaligus sebagai pelaksana tindakan. Penelitian ini dilakukan dalam 2 siklus dan tiap siklusnya terdiri dari 1) Perencanaan (planning), 2) Pelaksanaan (action), 3) Pengamatan (observasi), 4) Refleksi (reflection).

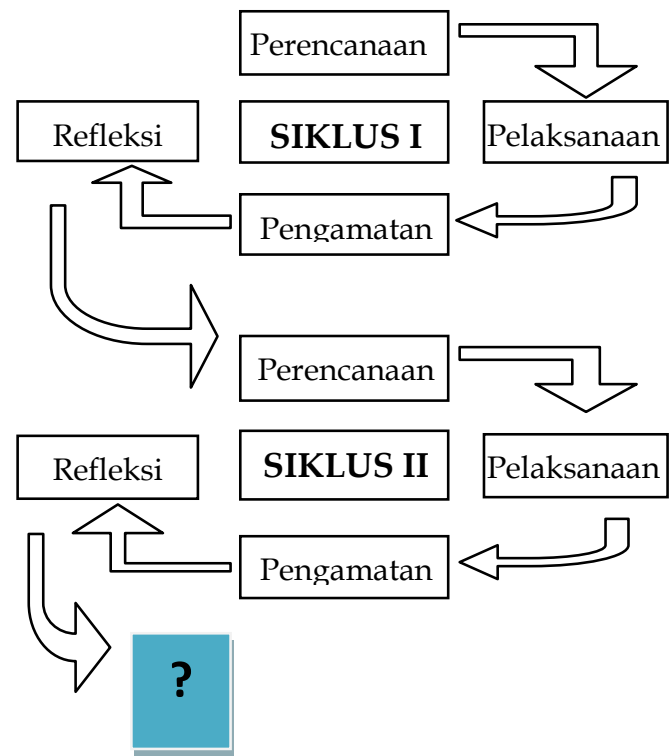

\section{Gambar 3.1 Siklus Model Penelitian Tindakan Kelas}

\subsection{Kegiatan Penelitian}

Adapun langkah - langkah yang dilakukan dalam penelitian ini adalah :

a. Tahap perencanaan Penelitian (Planning) Pada tahap ini kegiatan yang dilakukan adalah peneliti bekerja sama guru menetapkan pokok bahasan dan menyiapkan pokok bahasan dan menyiapkan Rencana Pelaksanaan Pembelajaran (RPP) yang berhubungan dengan materi pembelajaran.

b. Tahap Pelaksanaan penelitian (Acting) Pada tahap ini kegiatan yang dilakukan adalah pembelajaran dilaksanakan sesuai dengan rencana pembelajaran yang dibuat pada persiapan penelitian.Pembelajaran dimulai dengan memperkenalkan materi pelajaran sesuai dengan Rencana pelaksanaan Pembelajaran (RPP).

c. Tahap Pengamatan (Observasi)

Dalam tahap ini peneliti mengamati aktifitas selama proses belajar mengajar, meliputi : (1) proses penerapan model time token yang dilaksanakan guru ; (2) aktivitas siswa selama proses pembelajaran, diperoleh penerapan model terhadap aktivitas siswa.

d. Tahap Refleksi (Reflecting)

Pada Tahap refleksi ini, hasil yang diperoleh dari tahap pelaksanaan tindakan dan observasi dikumpulkan dan di analisis,sehingga diperoleh ada yang sudah baik dan yang tidak baik. Dari hasil refleksi ini dijadikan acuan untuk melakukan perbaikan pada siklus berikutnya

\subsection{Teknik Dan Alat Pengumpulan Data}

Dalam penelitian tindakan ini, teknik pengumpulan data yang digunakan penulis tertera pada Tabel 3.

Tabel 3. Teknik dan Alat Pengumpulan Data

\begin{tabular}{|l|l|l|l|}
\hline $\begin{array}{l}\text { Teknik } \\
\text { Pengum- } \\
\text { pul Data }\end{array}$ & $\begin{array}{l}\text { Alat } \\
\text { Pengum- } \\
\text { pul Data }\end{array}$ & $\begin{array}{l}\text { Aspek } \\
\text { yang } \\
\text { diamati }\end{array}$ & Waktu \\
\hline Tes & & $\begin{array}{l}\text { Akhir } \\
\text { pembelajaran }\end{array}$ \\
\hline & Soal & $\begin{array}{l}\text { Tes } \\
\text { hasil } \\
\text { belajar }\end{array}$ & \\
\hline $\begin{array}{l}\text { Tes } \\
\text { Objektif }\end{array}$ & $\begin{array}{l}\text { observa- } \\
\text { si }\end{array}$ & $\begin{array}{l}\text { Aktivi- } \\
\text { tas } \\
\text { belajar } \\
\text { siswa }\end{array}$ & $\begin{array}{l}\text { Pelaksanaan } \\
\text { pembelajaran }\end{array}$ \\
\hline Observasi & \multicolumn{2}{|l}{} \\
\hline
\end{tabular}

\subsubsection{Tes}

Tes yang digunakan dalam penelitian disesuaikan dengan tujuan yang hendak dicapai. Adapun tes yang diberikan berbentuk Pilihan berganda sebanyak 30 soal dengan empat pilihan,. Tes dilaksanakan untuk melihat hasil belajar siswa setelah pelaksanaan tindakan pada kompetensi yang telah ditetapkan.

\subsubsection{Observasi}

Observasi digunakan untuk mengumpulkan data tentang aktivitas belajar siswa dalam proses belajar mengajar dan penerapan model 


\section{UpayaMeningkatkan Keaktifan dan Hasil Belajar IImu Bahan Bangunan Melalui Penerapan Model Pembelajaran Time Token Pada Siswa Kelas X Program Keahlian Teknik Bangunan di SMK Negeri 2 Medan}

pembelajaran kooferatif tipe group investigasi. Observasi yang dilakukan dalam penelitian ini dengan mengunakan lembar Observasi aktivitas siswa dalam kelompok dengan menganalisis tingkat keaktifan siswa dalam proses belajar mengajar berlangsung.

\subsubsection{Skor maksimal}

Dalam penilaian aktivitas siswa memiliki nilai maksimum 16 dimana 16 adalah skor tertinggi yang diperoleh dari kriteria penilaian 4 aspek yang dinilai ada sebanyak 4 aktivitas siswa, sehingga guru dapat menilai aktivitas siswa dengan skor maksimum 16.

Penelitian tindakan kelas ini dilaksanakan di SMKN 2 Siatas Barita, Kompetensi keahlian teknik gambar bangunan pada mata pelajaran rencana anggaran biaya. Penelitian ini dilaksanakan pada kelas XII bulan Agustus 2014.

Adapun yang menjadi subyek penelitian ini adalah pembelajaran kolaboratif dan yang menjadi obyek adalah aktivitas dan hasil belajar TGB kelas XII SMKN 2 Siatas Barita. Berikut ini langkah-langkah pembelajaran kolaboratif:

a. Para siswa dalam kelompok menetapkan tujuan belajar dan membagi tugas sendirisendiri.

b. Semua siswa dalam kelompok membaca, berdiskusi, dan menulis..

c. Kelompok kolaboratif bekerja secara bersinergi mengidentifikasi, mendemontrasikan, meneliti, menganalisis, dan memformulasikan jawaban-jawaban tugas atau masalah dalam Materi atau masalah yang ditemukan sendiri.

d. Setelah kelompok kolaboratif menyepakati hasil pemecahan masalah, masing-masing siswa menulis laporan sendiri-sendiri secara lengkap.

e. Guru menunjuk salah satu kelompok secara acak (selanjutnya diupayakan agar semua kelompok dapat giliran ke depan) untuk melakukan presentasi hasil diskusi kelompok kolaboratifnya di depan kelas, siswa pada kelompok lain mengamati, mencermati, membandingkan hasil presentasi tersebut, dan menanggapi. Kegiatan ini dilakukan selama lebih kurang 20-30 menit.

f. Masing-masing siswa dalam kelompok kolaboratif melakukan elaborasi, inferensi, dan revisi (bila diperlukan) terhadap laporan yang akan dikumpulan.

> Laporan masing-masing siswa terhadap tugas-tugas yang telah dikumpulkan, disusun perkelompok kolaboratif.

> Laporan siswa dikoreksi, dikomentari, dinilai, dikembalikan pada pertemuan berikutnya, dan didiskusikan.

Prosedur penelitan merupakan tahapantahapan yang dilakukan dalam proses penelitian. Prosedur yang akan dilakukan adalah sebagai berikut:

\section{1) Siklus I}

\section{a. Perencanaan.}

Maka perencanaan yang akan dilakukan di siklus I adalah sebagai berikut :

(a) Merencanakan pembelajaran dengan Penerapan model kolaboratif.

(b) Menyiapkan sumber belajar

(c) Mempersiapkan format observasi untuk melihat tingkat hasil belajar siswa.

\section{b. Pelaksanaan tindakan}

Pelaksanaan tindakan yang akan dilakukan adalah

(a) Menyampaikan tujuan pembelajaran dan memberi informasi kepada siswa

(b) Memberi yang telah disusun sebelum nya dengan menerapkan model kolaboratif.

(c) Melaksanakan skenario yaitu penerapan model kolaboratif.

\section{c. Pengamatan}

Dalam pengamatan penelitian mengamati aktivitas siswa, yang ditulis pada lembar aktivitas yang telah disusun sebelum pengajaran dimulai, adapun aktivitas tersebut meliputi :

(a) Memberikan pertanyaan.

(b) Memberikan saran.

(c) Membuat kesimpulan dan,

(d) Memberikan jawaban.

\section{d. Refleksi}

Refleksi dilakukan dengan menganalisis hasil kerja peserta didik, lembar pengamatan yang telah diisi dari hasil diskusi yang 


\section{Togi Supriadi Napitupulu - Sempurna Perangi-Angin}

dilakukan peneliti dan pengamat. Adapun Refleksi :

(a) Mengkaji berbagai hal yang terjadi dan seharusnya dilakukan agar tidak terjadi kesalahan.

(b) Membuat kesimpulan sebagai dasar untuk melaksanakan siklusberikutnya

\section{2) Siklus II}

Pada prinsipnya semua kegiatan siklus II mirip dengan siklus I. Siklus II merupakan perbaikan pada siklus I, terutama didasarkan atas hasil refleksi pada siklus I. Secara garis besarnya adalah sebagai berikut.

\section{a. Perencanaan}

Meninjau kembali rancangan pembelajaran yang disiapkan untuk siklus 2 dengan melakukan revisi sesuai hasil refleksi 1.

Adapun perencanaan nya

(a) Mengidentifikasi masalah yang muncul pada siklus I dan penetapan alternatif pemecahan masalah

(b) Merencanakan pengembangan kompetensi yang dilakasanakan pada siklus II, untuk menyelesaikan permasalahan pada siklus I

\section{b. Pelaksanaan tindakan}

Pelaksanaan tindakan yang akan dilakukan adalah sama seperti pelaksanaan pada siklus I.

\section{c. Pengamatan}

Guru dan peneliti melakukan pengamatan yang sama seperti pada siklus I.

\section{d. Refleksi}

Refleksi pada siklus II ini dilakukan untuk melakukan penyempurnaan pembelajaran dengan menggunakan model kolaboratif di harapkan dapat meningkatkan Aktivitas dan hasil belajar peserta didik.

Teknik pengumpulan data dalam penelitian ini menggunakan tes dan Observasi Aktvitas

\section{1) Observasi Aktivitas siswa}

Obsevasi digunakan untuk mengumpulkan data tentang aktivitas belajar siswa dalam proses belajar mengajar dan penerapan model pembelajaran kolaboratif. Observasi yang dilakukan dalam penelitian ini dengan mengunakan lembar Observasi aktivitas siswa.

a. Aspek Aktivitas yang dinilai (a) Memberikan pertanyaan.

(b) Memberikan saran.

(c) Membuat kesimpulan dan,

(d) Memberikan jawaban

b. Kriteria skor

1 = Tidak pernah melakukan

$2=$ Dilakukan namun jarang

3 = Sering dilakukan

4 = Sangat sering dilakukan

c. Kriteria Penilaian

$$
\begin{array}{ll}
12-16 & \text { : Sangat Aktif } \\
8-12 & \text { : Aktif } \\
4-8 & \text { : Cukup Aktif } \\
0-4 & \text { : Kurang Aktif }
\end{array}
$$

Skor berdasarkan kriteria penilaian, maka 16 adalah skor tertinggi yang diperoleh dari kriteria penilian (4), dan aspek yang dinilai ada sebanyak 4 aspek, sehingga $4 \times 4=16$.

Dari hasil lembar aktivitas belajar siswa yang diperoleh kemudian dilakukan penganalisisan untuk menghitung persentase tingkat aktivitas siswa selama proses belajar mengajar berlangsung, yaitu dengan rumus:

Nilai Aktivitas siswa $=\frac{\text { Jumlahsiswayangaktif }}{\text { Jumlahseluruhsiswa }}$ XI 100

(Aqib, dkk. 2010)

Untuk mengetahui peningkatan aktivitas belajar siswa, jika dikelas telah terdapat $>70$ siswa yang mencapai kategori aktif dengan skor perolehan 12, maka ketuntasan secara keseluruhan telah mencapai.

\section{2) Tes Hasil Belajar}

Tes yang digunakan dalam penelitian disesuaikan dengan tujuan yang hendak dicapai. Adapun tes yang diberikan berbentuk Pilihan berganda sebanyak 40 soal dengan empat pilihan,dan dibagi dua, dimana 20 soal untuk siklus pertama dan 20 untuk siklus kedua. Dan setelah dilaksanakan Uji Intrumen Tes untuk melihat hasil Validitastes, Sehingga didapat pada Siklus pertama 3 (tiga) soal yang tidak Valid dan Siklus kedua terdapat 3 (soal) yang tidak Valid. maka setelah pelaksanaan tindakan pada kompetensi yang telah ditetapkan Secara lebih detail distribusi instrumen tes .

Persentase Nilai $=\frac{\text { Nilaiyangdiperole hsiswa }}{\text { jumla hnilai }}$ XI 100

Kategori penilaian:

$<70=$ Tidak Kompoten

$70-79=$ Cukup Kompoten

$80-89=$ Kompoten

$90-100=$ Sangat Kompoten 


\section{UpayaMeningkatkan Keaktifan dan Hasil Belajar IImu Bahan Bangunan Melalui Penerapan Model Pembelajaran Time Token Pada Siswa Kelas X Program Keahlian Teknik Bangunan di SMK Negeri 2 Medan}

Hasil belajar siswa di analisis dengan melihat ketuntasan belajar siswa.Berdasarkan Kriteria ketuntasan minimal siswa (KKM) yang ditetapkan dalam kompetensi dasar pada penelitian tindakan kelas ini, maka siswa dikatakan kopotensi jika siswa memperoleh skor $\geq 70$. Dan suatu kelas dikatakan tuntas terhadapa sustu materi pelajaran jika skor rata - rata kelas mencapai 70. Nilai rata - rata kelas dapat dihitung:

Nilai rata-rata kelas $($ mean $)=\frac{\sum x_{i}}{N}$,

Dengan :

$\Sigma \mathrm{XI}_{\mathrm{i}}=$ jumlah nilai siswa,

$\mathrm{N}=$ jumlah siswa.

Dari uraian diatas dapat diketahui ketuntasan secara keseluruhan (klasikal) dengan rumus sebagai berikut:

$$
P=\frac{\sum \text { SiswayangTuntasBelajar }}{\sum \text { Siswa }} \times 100 \%
$$

(Aqib, dkk 2010)

Keterangan:

$\mathrm{P}=$ Persentase ketuntasan belajar klasikal

Data hasil belajar siswa dianalisis dengan Kriteria Ketuntasan Minimal (KKM) yang ditetapkan oleh sekolah. Untuk menggunakan gambaran tentang hasil belajar siswa dinyatakan tuntas belajar jika siswa memperoleh skor 70 dan dinyatakan mencapai ketuntasan jika skor rata-rata kelas 70 atau 70\% menurut Kriteria Ketuntasan Minimal (KKM) yang ditetapkan oleh sekolah.

Berdasarkan kriteria ketuntasan belajar, jika kelas tersebut telah terdapat $70 \%$ siswa yang telah mencapai persentase Nilai $\geq 70$ maka ketuntasan secara keseluruhan telah tercapai. (Berdasarkan kriteria sekolah).

\section{Hasil Penelitian dan Pembahasan}

\subsection{Paparan Hasil Observasi Aktivitas Belajar} Siswa Siklus I

Ini terdapat 16 Siswa dikatakan Kurang Aktif, 4 Siswa dikatakan Aktif, Hal ini berarti bahwa Aktivitas belajar siswa belum sesuai dengan yang diharapkan, sehingga guru akan melanjutkan pembelajaran. Grafik yang menunjukkan tingkat Aktivitas belajar siswa selama proses belajar mengajar siklus I berlangsung dapat dilihat pada gambar dibawah ini :

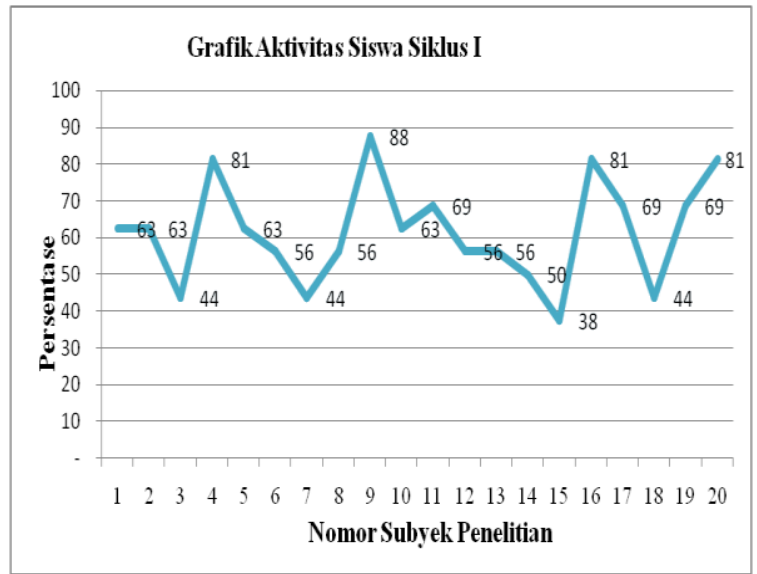

Gambar 1 Grafik Aktivitas Belajar Siklus I

\subsection{Paparan Hasil Belajar Siswa Siklus I}

Hasil belajar siswa diperoleh dari tes hasil belajar yang dikerjakan oleh siswa sesudah proses belajar mengajar dilaksanakan.

Dari hasil tes belajar siswa dengan kategori tidak kompeten sebanyak 17 orang, kompeten 3 orang cukup kompeten 1 orang. Dari nilai ideal 100, didapat nilai perolehan tidak tuntas dapat disebabkan oleh Pembagian kelompok yang tidak merata berdampak pada hasil belajar siswa yang belum memuaskan. Sehingga perlu dilanjut ke siklus II untuk meningkatkan aktivitas dan hasil belajar siswa dengan memperhatikan kelemahan yang terjadi selama pelaksanaan proses pembelajaran siklus I.

Grafik yang menunjukkan hasil belajar siswa selama proses belajar mengajar siklus I berlangsung dapat dilihat pada gambar dibawah ini:

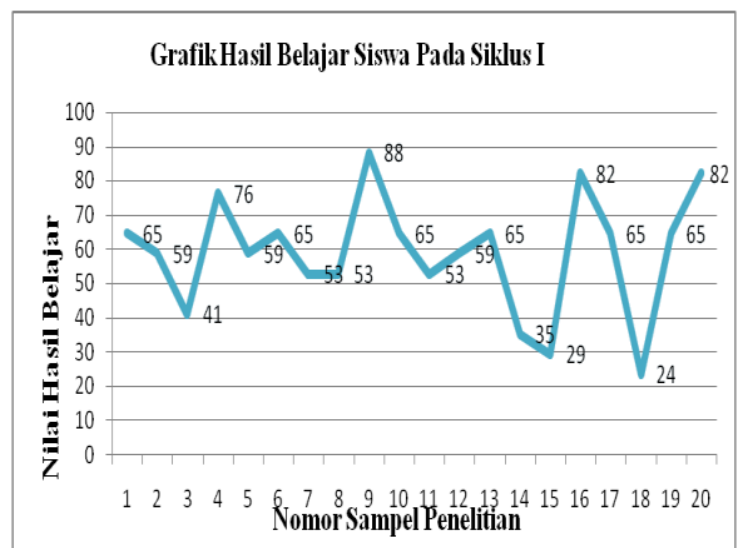

Gambar 2 Grafik Hasil Belajar Siklus I 


\subsection{Paparan Hasil Aktivitas Belajar Siswa Siklus II}

Hasil Observasi Aktivitas Siswa diperoleh dari kegiataan siswa dalam proses pembelajaran ini terdapat 5 Siswa dikatakan kurang Aktif, 11 siswa dikatakan Aktif, 4 Siswa dikatakan Sangat Aktif. Maka dapat disimpulkan Aktivitas pada Siklus II telah mengalami perbaikan dan peningkatan dari Siklus I. Grafik yang menunjukkan tingkat Aktivitas belajar siswa selama proses belajar mengajar siklus II berlangsung dapat dilihat pada gambar dibawah ini :

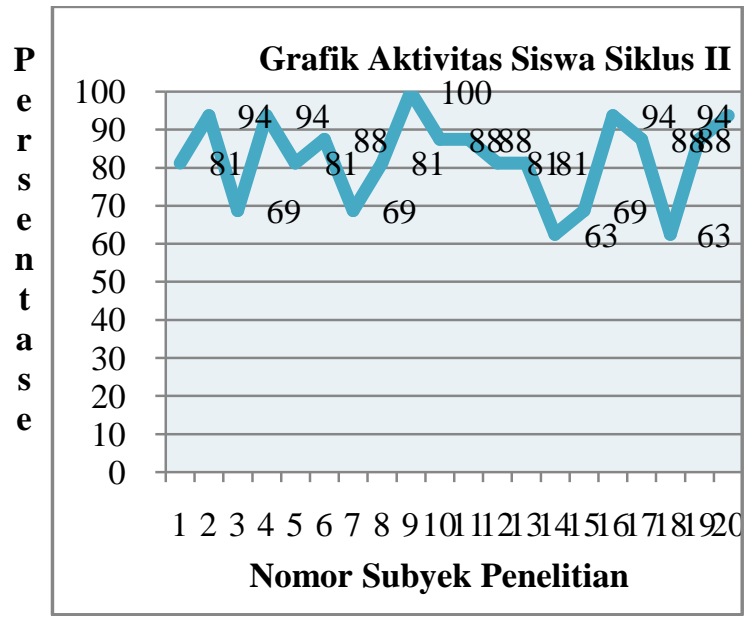

\section{Gambar 3 Grafik Aktivitas Belajar Siklus II}

\subsection{Paparan Hasil Belajar Siswa Siklus II}

Hasil belajar siswa diperoleh dari tes hasil belajar yang dikerjakan oleh siswa sesudah proses pembelajaran dilaksanakan.

Dari hasil tes belajar pada siklus II pada kategori Tidak Kompeten 5 Orang, kompeten 11 orang, dan sangat kompeten 4 orang. Dari nilai perolehan rata-rata dapat digolongkan dalam kategori kompeten. Sesuai dengan data tersebut maka penerapan model pembelajaran tipe kolaboratif dapat meningkatkan aktivitas dan hasil belajar rencana anggaran biaya siswa. Seperti yang dapat kita lihat pada gambar di bawah ini :.

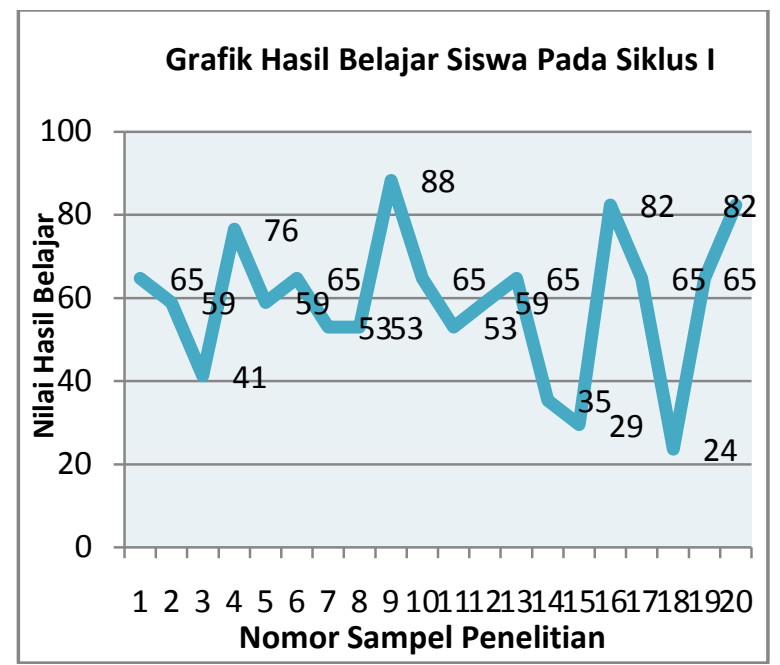

Gambar 4. Grafik Hasil Belajar Siklus II

Adapun keberhasilan yang diperoleh selama siklus kedua ini adalah sebagai berikut :

a. Aktivitas belajar siswa dalam proses belajar mengajar sudah mengarah kepembelajaran kolaboratif. Siswa mampu untuk saling berbagi dalam memecahkan masalah yang ada dalam kelompok sendiri maupun pada kelompok lainnya.

b. Hasil belajar siswa juga meningkat pada siklus II yaitu dengan rata-rata 69,81 pada siklus I meningkat menjadi 84,71 pada siklus II.

Hal ini membuktikan bahwa siklus selanjutnya tidak perlu dilakukan lagi. Oleh karena itu Penerapan pembelajaran kolaboratif dapat meningkatkan Aktivitas dan hasil belajar kelas XI Kompetensi Keahlian Teknik Gambar Bangunan pada kompetensi rencana anggaran biayadi SMK N 2 siatas Barita.

Dari hasil belajar pada siklus I dan siklus II dapat disimpulkan bahwa terjadi perbaikan pada setiap indikator, terutama pada Aktivitas dan hasil belajar siswa, sehingga penerapan Pembelajaran kolaboratif dapat meningkatkan aktivitas dan hasil belajar siswa pada mata pelajaran menerapkan dasar -dasar gambar teknik. Berikut grafik peningkatan aktivitas dan hasil belajar pada siklus I dan siklus II : 


\section{UpayaMeningkatkan Keaktifan dan Hasil Belajar Ilmu Bahan Bangunan Melalui Penerapan Model Pembelajaran Time Token Pada Siswa Kelas X Program Keahlian Teknik Bangunan di SMK Negeri 2 Medan}

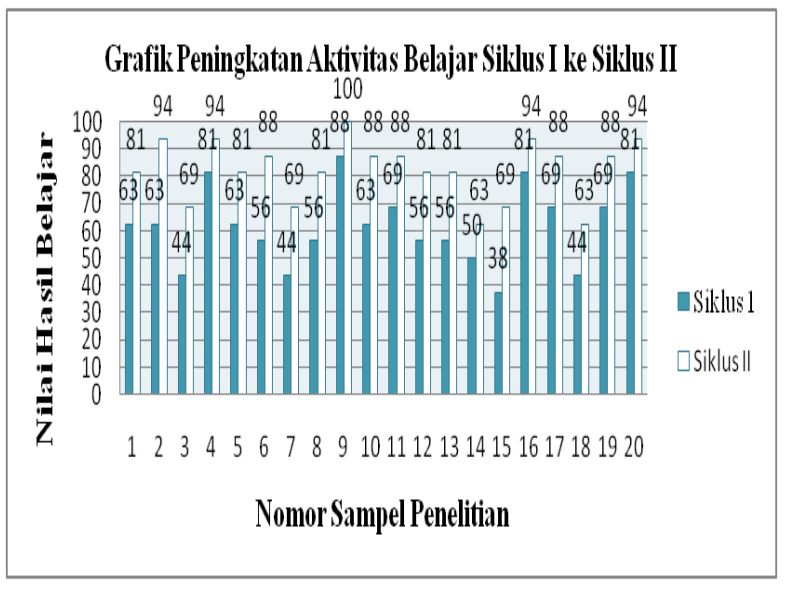

Gambar 5 Grafik Peningkatan Observasi Aktivitas Belajar Siklus I dan Siklus II

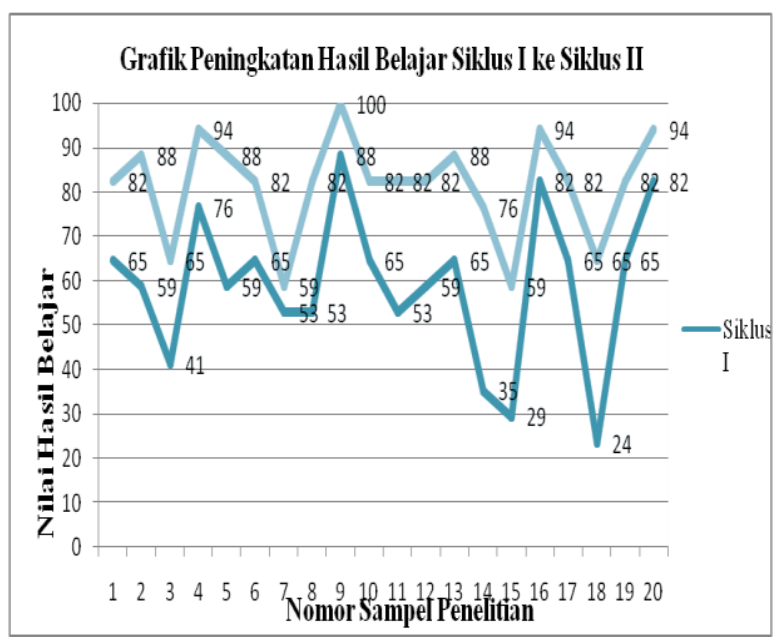

\section{Gambar 6 Grafik Peningkatan Hasil Belajar Siklus I dan Siklus II}

\subsection{Uji Hipotesis Penelitian}

Untuk menguji hipotesis dalam penelitian ini, digunakan teknik analisa statistik deskriptif yaitu mencari nilai rata-rata dan presentase keberhasilan belajar.

a. Dengan menerapkan pembelajaran model kolaboratif dapat meningkatkan aktivitas belajar siswa kelas XI kompetensi keahlian teknik gambar bangunan SMK N 2 Siatas Barita. Hipotesis pertama menyatakan dapat meningkatkan Aktivitas belajar siswa pada siklus I diketahui siswa yang memperoleh nilai dengan kategori Tidak aktif tidak ada,
Kurang aktif 7 orang (23,33\%), Cukup aktif 8 orang (26,67\%),Aktif 12 orang $(40,00 \%)$ dan Sangat aktif 3 orang $(10,00 \%)$. Dari nilai ideal 16, nilai perolehan rata-rata hanya 7,83 dan persentase klasikal 50,00 yaitu dalam kategori cukup aktif sehingga perlu dilakukan peningkatan pada siklus II. Setelah dilakukan pengamatan pada siklus II maka terjadi peningkatan terhadap Aktivitas belajar siswa yaitu dengan Aktivitas belajar siswa dengan kategori Tidak aktif tidak ada, Kurang aktif tidak ada, Cukup aktif 3 orang $(10,00 \%)$, Aktif 20 orang $(66,67 \%)$ dan Sangat Aktif 7 orang (23,33\%). Dari nilai ideal 16, nilai perolehan rata-rata hanya 10,9 dan persentase klasikalnya 90,00 yaitu tergolong dalam kategori aktif. Maka dapat disimpulkan dengan menerapkan Pembelajaran Model Kolaboratif dapat meningkatkan Aktifitas belajar siswa dalam mata pelajaran menerapkan dasar-dasar gambar teknik pada sub materi Mendeskipsikan peralatan gambar pada siswa kelas XI kompetensi keahlian teknik gambar bangunan SMK N 2 Siatas Barita.

b. Dengan menerapkan pembelajaran model kolaboratif dapat meningkatkan hasil belajar siswa kelas XI kompetensi keahlian teknik gambar bangunan SMK N 2 siatas Barita. Pada pre tes sebelum menggunakan model tipe kolaboratif terdapat 3 siswa ( $10,00 \%)$ dikatakan kompeten, 10 siswa ( 40,00\%) dikatakan cukup kompoten, 15 siswa ( $50,00 \%$ ) dikatakan tidak kompoten, dengan rata-rata 66,30, dengan persentase klasikal 10,00 yaitu kategori tidak kompoten ( Belum Tuntas ). Kemudian dilakukan pembelajaran kembali pada siklus I dengan menggunakan model kolaboratif, diketahui siswa yang memperoleh nilai dengan kategori tidak kompeten 11 orang $(36,67 \%)$, cukup kompeten 14 orang $(46,67 \%)$, dan kompeten 4 orang $(13,33 \%)$, dan sangat kompeten 1 orang $(3,33 \%)$. Dari nilai ideal 100, nilai perolehan rata-rata hanya 69,81 dengan persentase klasikal 16,67 yaitu masih dikatakan kategori Tidak Kompeten ( belum tuntas ), sehingga perlu dilakukan perbaikan pada siklus II. Setelah dilakukan pengamatan pada siklus II maka terjadi peningkatan terhadap hasil belajar siswa yaitu dengan 


\section{Togi Supriadi Napitupulu - Sempurna Perangi-Angin}

hasil belajar siswa dengan kategori tidak kompeten tidak ada, ,cukup kompeten 8 orang $(26,67 \%)$, kompeten 15 orang $(50,00 \%)$, dan sangat kompeten 7 orang $(23,33 \%)$. Dari nilai ideal 100, nilai perolehan rata-rata hanya 84,71 dengan persentase klasikal 73,33 tergolong dalam kategoti kompeten. Maka dapat disimpulkan dengan menerapkan pembelajaran model kolaboratif dapat meningkatkan hasil belajar RAB siswa kelas XI kompetensi keahlian teknik gambar bangunan SMKN 2 Siatas Barita.

\section{Kesimpulan, Implikasi dan Saran \\ 5.1 Kesimpulan}

Dari hasil analisis data dan pembahasan maka dapat diambil kesimpulan, yaitu aktivitas belajar siswa selama penerapan model pembelajaran kolaboratif pada siklus I kurang mencapai standar minimal yang diharapkan, sehingga perlu dilakukan siklus lanjutan (siklus II). Hasil belajar siswa setelah dilakukan penerapan model pembelajaran kolaboratif adalah mengalami peningkatan, yaitu dari siklus I dengan rata-rata 55 meningkat menjadi 81 pada siklus II dengan mengalami peningkatan sebesar $22 \%$. Dari hasil peningkatan hasil belajar tersebut berarti penerapan model pembelajaran kolaboratif pada materi pekerjaan struktur dan non struktur serta perhitungan pekerjaan struktur dan non struktur mengalami peningkatan. Oleh karena itu, penerapan model pembelajaran kolaboratif dapat meningkatkan aktivitas dan hasil belajar RAB Kompetensi Keahlian Teknik Gambar Bangunan SMKN 2 Siatas Barita.

\subsection{Implikasi}

Hasil kesimpulan menyatakan siswa yang diajar menggunakan model pembelajaran kolaboratif memperoleh hasil belajar RAB lebih tinggi jika dibandingkan dengan siswa yang diajar dengan metode pembelajaran Konvensional. Dengan diterimanya hipotesis dalam penelitian ini, maka model pembelajaran kolaboratif ini dapat dijadikan sebagai pilihan metode pembelajaran bagi guru khususnya guru standar kompetensi RAB dalam melaksanakan proses pembelajaran.

Penggunaan model pembelajaran yang tepat akan menciptakan suasana belajar yang lebih baik demi tercapainya hasil belajar yang baik pula. Penerapan model pembelajaran kolaboratif menjadi salah satu bukti bahwa pembelajaran juga menuntut aktivitas siswa dan guru untuk mengembangkan potensi yang ada di dalam diri siswa.

\subsection{Saran}

Berdasarkan kesimpulan di atas maka disarankan beberapa hal sebagai berikut :

a. Sebaiknya guru memberikan motivasi dan dorongan kepada siswa setiap kali sebelum pembelajaran dimulai.

b. Situasi ruang belajar harus menarik dan menantang dalam proses belajar mengajar.

c. Guru harus melatih keterampilan dan mendorong keberanian siswa dalam menjawab dan mengajukan pertanyaan.

d. Bagi guru khususnya guru standar kompetensi RAB sebaiknya menggunakan model pembelajaran kolaboratif sebagai salah satu alternative dalam mata pembelajaran RAB untuk meningkatkan aktivitas dan hasil belajar siswa.

e. Siswa harus lebih serius dalam mendalami materi pembelajaran dan lebih sering melakukan kerja kelompok dalam membahas materi.

f. Siswa lebih aktif dalam belajar dengang menggunakan model kolaboratif.

g. Pihak sekolah harus menambah referensi materi yang akan diajarkan sehingga perhatian siswa lebih terfokus pada materi pelajaran dalam meningkatkan hasil belajar siswa.

h. Untuk penelitian lebih lanjut.

\section{Daftar Pustaka}

Arikunto, S. 2003. Manajemen Penelitian. Jakarta: Rineka Cipta

Arikunto, S. 2006. Dasar-Dasar Evaluasi Pendidikan. Jakarta: Bumi Aksara

Arikunto, dkk. 2008. Penelitian Tindakan Kelas. Jakarta : Bumi Aksara.

Djamarah, dkk. 2008. Strategi Belajar Mengajar. Jakarta : Rineka Cipta.

Daryanto, 2010. Evaluasi Hasil Belajar. Jakarta: Rineka Cipta.

Hamalik, O. 2009. Proses Belajar Mengajar. Jakarta : Bumi Aksara

Istarani. 2011. 58 Model Pembelajaran Inovatif. Medan : Media Persada 


\section{UpayaMeningkatkan Keaktifan dan Hasil Belajar Ilmu Bahan Bangunan Melalui Penerapan Model Pembelajaran Time Token Pada Siswa Kelas X Program Keahlian Teknik Bangunan di SMK Negeri 2 Medan}

Jakob Et Al. 1996. Belajar Tentang kehidupan Nyata. Http:/ / Tulisansingkatemail. blogspot.com/?view=sidebar.

Diakses Tangggal 27 April 2014

John M. 1991. Metode Pembelajaran Kolaboratif. Http:/ / Tulisansingkatemail. blogspot.com/?view=sidebar. Diakses Tangggal 27 April 2014

Johnsons. 1974. Unsur Dasar Pembelajaran Kolaboratif. Http:// Tulisansingkatemail. blogspot.com/?view=sidebar. Diakses Tangggal 27 April 2014

Kunandar. 2008. Langkah Mudah Penelitian Tindakan Kelas Sebagai Pengembangan Profesi Guru. Jakarta : Rajawali Pers

Mudyaharjo. 2001. Hakikat Pendidikan. Http:// Belajarjadiguruprofesional.

blogspot.com/?view=sidebar. Diakses Tangggal 27 April 2014

Mukomoko. 2011. Dasar Penyusunan Anggaran Biaya Bangunan. Jakarta : Yofa Mulia Offset

Nurasman. 2006. Model Pembelajaran Kolaboratif. Error! Hyperlink reference not valid. Diakses tanggal 29 oktober 2013

Reid. 2004. Tahapan Mengembangkan Pembelajaran Kolaboratif. Http:// Tulisansingkatemail. blogspot.com/?view=sidebar. Diakses Tangggal 27 April 2014

Rohani, A. 2004. Pengelolaan Pengajaran. Jakarta: Rineka Cipta.

Sanjaya. 2006. Strategi Pembelajaran. Jakarta : Kencana.

Sardiman. 2009. Interaksi dan Motivasi Belajar Mengajar. Jakarta : Raja Grafindo Persada.

Slameto. 2003. Belajar dan Fakto-faktor Yang Mempengaruhinya. Jakarta : Rineka Cipta

Smith \& MG. 1992. Metode Kolaboratif Didasarkan Pada Asumsi-Asumsi Mengenai Proses Belajar Siswa. Http:// Tulisansingkatemail. blogspot.com/?view=sidebar. Diakses Tangggal 27 April 2014

Sudjana, N. 2009. Penilaian Hasil Proses Belajar Mengajar. Bandung : Remaja Rosdakarya

Sugiono. 2009 ; 96. Rancangan Penelitian. Jakarta : Rineka Cipta

Ted Panitz. 1996. Pengertian Kolaboratif. Http:// Tulisansingkatemail.

blogspot.com/?view=sidebar. Diakses Tangggal 27 April 2014
Trianto. 2007. Model- Model Pembelajaran Inovatif Berorientasi Konstruktivistik. Jakarta: Prestasi Pustaka.

Yasa. 2008. Prestasi Belajar. http:/ /ipoteswordpress.com/2009/05/24. Diakses tanggal 29 september 2013. 